\title{
Bromatological and microbiological characteristics of sugarcane silages treated with calcium oxide
}

\author{
Jucilene Cavali ${ }^{1}$, Odilon Gomes Pereira ${ }^{1}$, Sebastião de Campos Valadares Filho ${ }^{1}$, Edson \\ Mauro Santos ${ }^{2}$, Gleidson Giordano Pinto de Carvalho ${ }^{3}$, Márcia Vitória Santos ${ }^{1}$, Marlos \\ Oliveira Porto $^{1}$, Juliana Ferraz Huback Rodrigues ${ }^{1}$
}

\footnotetext{
1 Universidade Federal de Viçosa, Departamento de Zootecnia - Viçosa, MG.

2 Universidade Federal da Paraíba - Areia, PB.

3 Universidade Federal da Bahia - Salvador, BA.
}

\begin{abstract}
It was evaluated the addition of calcium oxide $(0 ; 0.5 ; 1.0 ; 1.5$; and $2.0 \%$ of dry matter) effect on the chemical composition and ruminal degradability of the dry matter and neutral detergent fiber, on the losses of dry matter, and on the microbial population in sugar cane silages. A design with five levels of calcium oxide and three replications was used. All the variables were influenced by the addition of calcium oxide in the silages, except the composition in acid detergent insoluble protein, water soluble carbohydrates and lignin. The dry matter content and $\mathrm{pH}$ linearly increased while the contents of organic matter, hemicellulose and crude protein linearly decreased with the levels of calcium oxide. Neutral detergent fiber corrected for ashes and protein and acid detergent fiber were adjusted for the quadratic models with calculated minimal values of 33.3 and $22.5 \%$ for the levels 1.73 and $1.49 \%$ of calcium oxide, respectively. The in vitro digestibility of the dry matter and the content of amoniacal nitrogen adjusted to quadratic models with maximal levels of $80.1 \%$ and $9.1 \%$ for the levels of 1.8 and $0.7 \%$ of calcium oxide, respectively. The minimal production of gas $(3.18 \%)$ was observed at the level of $1.39 \%$ of calcium oxide. Production of effluent and recovery of dry matter of the ensiled mass showed a reduction and a linear increase, respectively, with addition of calcium oxide. The highest lactic acid bacterial population was observed in the silage treated with $1.5 \%$ of calcium oxide. The addition of calcium oxide increased degradability of the soluble fraction of the dry matter, which was higher than $50 \%$ and reduced the non-degradable fraction of the neutral detergent fiber. Addition of calcium oxide level higher than $1.0 \%$ in the sugar cane during ensilage improves in vitro dry matter digestibility and the recovery of dry matter, increases populations of lactic acid bacteria and reduces production of yeasts.
\end{abstract}

Key Words: effluent, ensilage, microbial population, nutritional value, whitewash

\section{Características bromatológicas e microbiológicas de silagens de cana-de- açúcar tratadas com óxido de cálcio}

RESUMO - Avaliou-se o efeito da adição de óxido de cálcio $(0 ; 0,5 ; 1,0 ; 1,5$ e 2,0\%, da MS) na composição química e degradabilidade ruminal da matéria seca e fibra de detergente neutro (FDN), nas perdas de MS e na população microbiana em silagens de cana. Foi utilizado um delineamento com cinco níveis de óxido de cálcio e três repetições. Todas as variáveis foram influenciadas $(\mathrm{P}<0,05)$ pela adição de óxido de cálcio nas silagens, exceto a composição em proteína insolúvel em detergente ácido, carboidratos solúveis em água e lignina. O teor de matéria seca e o pH aumentaram linearmente, enquanto que os de matéria orgânica, hemicelulose e proteína bruta reduziram, também linearmente, com os níveis de óxido de cálcio. A fibra em detergente neutro corrigida para cinzas e proteína e a fibra em detergente ácido ajustaram-se a modelo quadrático, com valores mínimos calculados de 33,3 e 22,5\% para os níveis de 1,73 e 1,49\% óxido de cálcio, respectivamente. A digestibilidade in vitro da MS (DIVMS) e o conteúdo de nitrogênio amoniacal ajustaram-se a modelos quadráticos, com valores máximos de 80,1 e $9,1 \%$ para os níveis de 1,8 e $0,7 \%$ de óxido de cálcio, respectivamente. A produção mínima de gás $(3,18 \%)$ foi observada no nível de $1,39 \%$ de óxido de cálcio. A produção de efluente e a recuperação de MS da massa ensilada apresentaram redução e aumento linear, respectivamente, com adição de óxido de cálcio. A maior população de bactérias ácido-lácticas foi observado na silagem tratada com $1,5 \%$ de óxido de cálcio. A adição de óxido de cálcio aumentou a degradabilidade da fração solúvel da MS, que foi superior a 50,0\% e reduziu a fração indegradável da FDN. A adição de óxido de cálcio em níveis acima de 1,0\% na cana-de-açúcar durante a ensilagem melhora a DIVMS e a recuperação da matéria seca, aumenta as populações de bactérias ácido-lácticas e reduz a produção de leveduras.

Palavras-chave: cal, ensilagem, efluente, população microbiana, valor nutritivo 


\section{Introduction}

The culture of sugarcane is of great importance for the ruminant nutrition, during dry season. However, the restrictions for the use of sugarcane include the need for daily cutting and the nutritional value, which is limited by reduced protein content and low dietary fiber (Barbosa \& Silveira, 2006). Ensilage of sugarcane can improve the efficiency of the harvest by solving problems regarding the logistics of food for large flocks and allowing sugarcane to be cut from large areas in a short time (Pedroso et al., 2005). Sugarcane can be ensiled like other roughages because it presents the main favorable characteristics for processing, including a dry matter content of approximately 250 to $300 \mathrm{~g} / \mathrm{kg}$ a soluble carbohydrate around $100 \mathrm{~g} / \mathrm{kg}$ of natural matter and the ability to be buffered so as to allow $\mathrm{pH}$ values decrease to around 3.5 (Valvasori, 1995). Issues for the production of sugarcane ensilages are related to the biochemical reaction catalyzed by the yeasts, making sugarcane a high producer of $\mathrm{CO}_{2}$, water and ethanol (Alli et al., 1983; Kung et al., 2003). The losses of dry matter mainly proceeding from $\mathrm{CO}_{2}$ produced by route of the ethanol, that responded for $54 \%$ of the total dry matter losses occurred until the $45^{\text {th }}$ day of ensilage, as well as of the volatilization of the ethanol that reduces up to $50 \mathrm{~g} / \mathrm{kg}$ the concentration of alcohol in the dry matter of sugarcane silages (Pedroso et al., 2005), resulting in larger losses of dry matter and nutritious value, besides reducing around of $750 \mathrm{~g} / \mathrm{kg}$ in contents of soluble carbohydrate (Silva et al., 2008; Pedroso et al., 2005).

Researchers have observed high losses in the quality of sugarcane silages compared to fresh sugarcane when the first was produced without additives, mainly because of an increase in the constituent yields of the cellular wall (Andrade et al., 2001; Pedroso et al, 2005; Bernardes et al., 2007). Another factor to be considered is the loss of effluents and gases during the fermentations, which depriciates the final quality of the silage.

The use of additives is essential for ensilage of the sugarcane because they control the metabolic activity of yeast population, reducing fermentative losses of DM (Nussio \& Schmidt, 2004; Siqueira et al., 2007) justifying this practice. The micro-processed calcium oxide additive has presented promising results on improving the chemical characteristics of silages due to hydrolysis fraction fiber, break of lignocellulosic hydrogen binds and by solubling and increasing in vitro NDF digestibility (Van Soest, 1987, Santos et al., 2008) losses by effluents and gas (Santos et al., 2008) and increasing the in vitro DM digestibility contents around of $275 \mathrm{~g} / \mathrm{kg}$ regarding to control silage (Balieiro Neto et al., 2007).

The aim of this work was to evaluate the effect of calcium oxide levels on the chemical composition and ruminal degradability of dry matter and neutral detergent fiber, as well as to evaluate the losses of DM and the microbial population on sugarcane silages.

\section{Material and Methods}

The sugarcane (Saccharum officinarum Linn.) cultivar IAC 86-2480 was harvested 18 months after planting cut into particles of approximately $2 \mathrm{~cm}$ each using a stationary machine. The treatments consisted of five calcium oxide levels $(0,5,10,15$ and $20 \mathrm{~g} / \mathrm{kg}$, expressed as fed basis) added to the sugarcane with tree replications in each treatment. The calcium oxide $(\mathrm{CO})$, in the form of lime micro processed or micro-pulverized, presented the following levels of guarantee (expressed in $\mathrm{g} / \mathrm{kg}$ ): $\mathrm{MgO}=5 ; \mathrm{Al}_{2} \mathrm{O}_{3}=3$; $\mathrm{SiO}_{2}=14 ; \mathrm{Fe}_{2} \mathrm{O}_{3}=2$; total $\mathrm{CO}=900$; available $\mathrm{CO}=873$; $\mathrm{CO}_{2}=15$ and $\mathrm{S}=0.7 \mathrm{~g} / \mathrm{kg}$ and it is recommended for the hydrolyses of the sugarcane, once this product is totally different from the virgin whitewash used in civil construction and it is adequate for animal feeding because it is free of toxicant substances as dioxins and furans in its process production (Santos et al., 2009). Calcium oxide powder was added into mounts of the cut sugarcane forming a totally homogenized mixture when it was collected a sample of $500 \mathrm{~g}$ for each treatment.

After calcium oxide levels addition, the sugarcane was ensiled in triplicate per treatment in $15 \mathrm{~L}$ plastic buckets (silos) with a Bünsen valve in the lid, which allows the gases originated from fermentation to escape. It takes one hour and half to perform the process of cutting and ensilage. The cloth bag containing $4 \mathrm{~kg}$ of sand dried in an air forced oven $55^{\circ} \mathrm{C}$ for approximately 72 hours was placed at the base of each silo or bucket for subsequent estimates of effluent production. The mean and standard error to mass forage ensiled into the silos was $11.06 \pm 0.26 \mathrm{~kg}$ and the mean of specific mass of $830 \mathrm{~kg}$ forrage $/ \mathrm{m}^{3}$. The silos were closed with an adhesive tape, weighed and stored in a covered area at room temperature until the moment of opening, which took place 40 days after the ensilage.

Upon opening of the silos, the material was weighed to determine the losses from fermentation; samples were collected to determine $\mathrm{pH}$, total amoniacal/ $\mathrm{N}\left(\mathrm{NH}_{3}-\mathrm{N}\right)$, microbiological counting and to determine the pre-dry. The samples of silages intended for drying were conditioned in bags of paper and placed in air forced stove at $55^{\circ} \mathrm{C}$ for 72 hours, then ground in a Wiley-type mill to particles of 1 and $2 \mathrm{~mm}$. 
The samples grounded in a $1 \mathrm{~mm}$ screen were used to determine the dry matter at $105^{\circ} \mathrm{C}$, neutral detergent fiber (NDF) (in agreement with Mertens, 2002), acid detergent fiber (ADF), hemicellulose (HEM), sulfuric acid lignin (Robertson \& Van Soest, 1981), crude protein (CP), water soluble carbohydrates (WSC) according to methodology described by Deriaz (1961) and in vitro dry matter digestibility (IVDMD) in 48 hours. Neutral detergent insoluble protein (NDIP) and acid detergent insoluble protein (ADIP) were determined according to the description of Licitra et al. (1996), and neutral detergent fiber corrected to ash and protein (NDFap) was determined according to Hall (2003). The material ground into $2 \mathrm{~mm}$ particles was used to analyze in situ DM degradability (DMDg) and NDF degradability (NDFDg).

For $\mathrm{pH}$ analysis, samples of $25 \mathrm{~g}$ were collected, into which $100 \mathrm{~mL}$ of distilled water was added; after resting for 2 hours, the $\mathrm{pH}$ was read using a potenciometer. In another sample of $25 \mathrm{~g}, 200 \mathrm{~mL}$ of a solution of $\mathrm{H}_{2} \mathrm{SO}_{4}, 0.2 \mathrm{~N}$ was added. The sample then remained at rest for 48 hours in a refrigerator, followed by filtering with a Whatman ${ }^{\circledR} 54$ type paper-filter. $\mathrm{NH}_{3}-\mathrm{N}$ content as a percentage of $\mathrm{N}$-total was dosed in the filtered sample using $\mathrm{KOH}$ at $2 \mathrm{~N}$. The $\mathrm{pH}$ and $\mathrm{NH}_{3}-\mathrm{N}$ were determined according to method described by Bolsen et al. (1992).

The bags used were non-woven textile (NWT) with density of $100 \mathrm{~g} / \mathrm{m}^{2}$ and measuring $7 \times 7 \mathrm{~cm}$, in which $2.5 \mathrm{~g}$ of each sample were added, previously grounded at $2 \mathrm{~mm}$ in order to maintain a relation of approximately $20 \mathrm{mg} \mathrm{DM} / \mathrm{cm}^{2}$ in the superficial area of the bag (Nocek, 1988). The incubation periods were $6,24,30,36,48,72,96$ and 144 hours. The first bags incubated were the ones that stayed 144 hours in the rumen and the other bags were added at selected times so that all bags were withdrawn together. Two bags of each feed were incubated in the rumen of two crossbred, non-suckling cows fed diets based in $70 \%$ of corn silage. The samples were incubated through rumen canulla, fixed on a steel chain with a weight in an extremity allowing its immersion in the ruminal content. After the incubation period, the bags were washed in running water and remained in the forced air oven at $55^{\circ} \mathrm{C}$ for 72 hours, being the NDF content quantified afterwards in the incubation residues.

The DMDg was calculated through the equation proposed by Ørskov \& McDonald (1979): $D=A+B *[1-$ $\left.\operatorname{Exp}\left(k_{d} * t\right)\right]$, where $D=$ degradable fraction in available time $(\%) ; A=$ soluble fraction $(\%) ; B=$ potentially degradable insoluble fraction $(\%) ; \mathrm{k}_{\mathrm{d}}=$ rate of degradation of the fraction $B\left(\mathrm{~h}^{-1}\right)$; and $t=$ time $(\mathrm{h})$. The NDFDg was approximated using the model proposed by Mertens \&
Loften (1980): $D=B_{p} * \operatorname{Exp}\left(k_{d} *(t-L)+I\right.$, wherein $B=$ potentially degradable fraction $(\%) ; I=$ non-degradable fraction $(\%) ; L=$ lag time, and $k_{d}$ and $t$ are as defined previously.

The microbiological analyses were determined as described by González \& Rodriguez (2003). For 25 g of sample, $225 \mathrm{~mL}$ of distilled water was added. The mixture was then placed in an industrialized liquidizer for nearly 1 minute. One mL or $0.1 \mathrm{~mL}$ of the mixture was then pipetted; the dilution varied from $10^{-1}$ to $10^{-9}$, using bottles of water with $99.9 \mathrm{~mL}$ of a phosphate buffer solution with a $\mathrm{pH}$ of 7.2 for the dilution. Plating was carried out in duplicate for each medium culture. Populations were determined by the selective culture techniques, consisting of the following denominations: Ágar Rogosa SL (DIFCO, Detroit) for counting lactobacillus after a 48 hour-incubation in a stove at temperature of $37^{\circ} \mathrm{C}$, Ágar BDA, for counting yeasts and molds after 5-7 days of incubation at room temperature, and Ágar Violet Red Bile (DIFCO, Detroit) for counting enterobacteria, after a 24 hour-incubation at a temperature of $35^{\circ} \mathrm{C}$. The plates were considered susceptible to counting if they had values between 30 and 300 , colony-forming units (cfu) on a Petri dish. Results were obtained through averaging two plates of the selected dilution.

Losses of dry matter as gases and effluents were quantified by the difference in weight according to the methodology described by Siqueira et al. (2007). The gas losses was calculated based on the difference in dry mass weight, using the equation: $G=(P C i-P C f) /(M F i \times M S i)$ $x 1.000$, where $G=$ loss of gas $(\mathrm{g} / \mathrm{kg}$ of DM); $P C i=$ weight of the full bucket upon closure $(\mathrm{kg}) ; P C f=$ weight of the full bucket upon opening (kg); $M F i=$ mass of forage upon closure $(\mathrm{kg}) ; M S i=$ content of DM upon closure. The effluent losses were calculated by the difference in weight of sand related to the mass of forage upon closure of the silos: $E=[(P V f-T b)-(P V i-T b)] / M F i \times 100$, where $E=$ production of effluents $(\mathrm{kg} /$ ton of $\mathrm{DM}) ; P V i=$ weight of the empty bucket + weight of the sand upon closure $(\mathrm{kg})$; $P V f=$ weight of the empty bucket + weight of the sand upon opening (kg); $T b=$ tare of the bucket; and $M F i=$ mass of forage upon closure $(\mathrm{kg})$. The rate of DM recovery (DMR) was obtained by the difference in weight of the mass of forage at the moment of ensilage and at the opening of the silos and their respective dry matter yields, according to the equation $D M R=(M F f \times M S f) /(M F i \times M S i) \times 100$ where $D M R=$ rate of DM recovery $(\%) ; M F i=$ mass of forage upon closure $(\mathrm{kg})$; MSi = yield of dry matter in the forage upon closure $(\%) ; M F f=$ mass of forage upon opening $(\mathrm{kg})$; and $M S f=$ yield of dry matter in the forage upon opening $(\%)$. 
The data obtained were subjected to variance and regression analyses with a $5 \%$ of significance using PROC GLM of SAS system (SAS, 2003), according to statistic model of $\mathrm{Y}_{\mathrm{ij}}=\mu+\mathrm{T}_{\mathrm{i}}+\varepsilon_{\mathrm{ij}}$ where: $\mathrm{Y}_{i j}=$ observation referent to treatment $i$ in replication $j ; \mu=$ general mean; $\mathrm{T}_{i}=$ effect of treatment $i ; \varepsilon_{i j}=$ aleatory error referent to effect of treatment $i$ in replication $j$, suppose $\sim \operatorname{NID}\left(0, \sigma^{2}\right)$ (normal and independently distribution). The choice of regression equations was based on the coefficient of determination and on the significance of the regression coefficients, according to t-tests.

\section{Results and Discussion}

The average content of dry matter of $267 \mathrm{~g} / \mathrm{kg}$ in the sugarcane before ensilage did not prevent production of effluents (Table 1). This content of sugarcane are similar to those reported by Bernardes et al. (2007), who registered an average value of $270 \mathrm{~g} / \mathrm{kg}$ and lower to those reported by Santos et al. (2008) and Siqueira et al. (2007) with $350 \mathrm{~g} / \mathrm{kg}$. According to Jones \& Jones (1995) the dry matter content of $250 \mathrm{~g} / \mathrm{kg}$ would be sufficient to avoid the significant production of effluents.

The sugarcane without additives used for ensilage presented low contents of total non digestible fiber and smaller average values of non digestible fiber when treated with calcium oxide because of the speed with which the additive acts on the sugarcane due to fraction fiber hydrolysis plus the fact that during the process of drying sample in the forced air oven at $55^{\circ} \mathrm{C}$ to prepare to analysis the reaction could occur, as reported by Balieiro Neto et al. (2007). Pires et al. (2006), evaluating the use of doses of $\mathrm{NaOH}(0,25,50$ and $75 \mathrm{~g} / \mathrm{kg}$ of the DM) in the stock of the sugarcane 1, 3, 5 and 7 days after the harvest, did not note any effect for time in any of the constituent cell walls despite the reduction of fiber contents caused by the levels of $\mathrm{NaOH}$, proving the quick action of the alkaline hydrolysis.

The contents of water soluble carbohydrates, which varied from 369.0 to $421.0 \mathrm{~g} / \mathrm{kg}$, can be considered normal for sugarcane (Table 1). Values of water soluble carbohydrates similar to those in the present study were reported by Alli et al. (1982) and Freitas et al. (2006), who found a range of 410.0 to $540.0 \mathrm{~g} / \mathrm{kg}$ of water soluble carbohydrates in the sugarcane harvested at different dates. However, according to Silva et al. (2008) the ethanol production in silages would be null if sugarcane plant had only $124 \mathrm{~g} / \mathrm{kg}$ of water soluble carbohydrates on dry matter basis.

Most of the variables were influenced $(\mathrm{P}<0.05)$ by the level of calcium oxide in the silage, with the exception of acid detergent insoluble protein, water soluble carbohydrates and lignin (Table 2). The amount of dry matter in the silages increased linearly with calcium oxide levels (Table 3). Because yeast have an important role in the fermentation of sugars to ethanol in sugarcane by reducing dry matter contents mainly by production of $\mathrm{CO}_{2}$, the increase of dry matter in silages can be explained by reducing the yeast with the addition of calcium oxide. The alkaline action of additive increasing $\mathrm{pH}$ at the moment of ensilage (Table 1) and the osmotic pressure in the ensiled mass might turn the environment inappropriate to development of yeast population and giving chance to increment of Lactobacillus under homolatic fermentation, decreasing dry matter losses in silages mainly by gases losses (Bernades et al., 2009). Increases in dry matter regarded to calcium oxide levels were also observed by Balieiro Neto et al. (2007).

The amount of crude protein decreased linearly with calcium oxide level (Table 3) which might have happened because of the proportional dilution of wall cell components

Table 1 - Chemical composition of sugarcane before the ensilage

\begin{tabular}{|c|c|c|c|c|c|}
\hline \multirow[t]{2}{*}{ Variables } & \multicolumn{5}{|c|}{ Calcium oxide levels ( $\mathrm{g} / \mathrm{kg}$ as fed basis) } \\
\hline & 0 & 5 & 10 & 15 & 20 \\
\hline Dry matter $(\mathrm{g} / \mathrm{kg})$ & 266 & 269 & 272 & 263 & 267 \\
\hline Organic matte $\mathrm{g} / \mathrm{kg}$ of $\mathrm{DM}$ & 974 & 950 & 940 & 915 & 890 \\
\hline Crude protein $\mathrm{g} / \mathrm{kg}$ of $\mathrm{DM}$ & 26.6 & 25.7 & 19.0 & 24.5 & 19.3 \\
\hline Neutral detergent insoluble protein $\mathrm{g} / \mathrm{kg}$ of $\mathrm{CP}$ & 155 & 195 & 279 & 263 & 253 \\
\hline Acid detergent insoluble protein $\mathrm{g} / \mathrm{kg}$ of $\mathrm{CP}$ & 99.5 & 134 & 154 & 127 & 140 \\
\hline Neutral detergent fiber $\mathrm{g} / \mathrm{kg}$ of $\mathrm{DM}$ & 440 & 406 & 400 & 373 & 336 \\
\hline Neutral and detergent fiber corrected for ash and crude protein $\mathrm{g} / \mathrm{kg}$ of $\mathrm{DM}$ & 419 & 367 & 361 & 325 & 299 \\
\hline Acid detergent fiber $\mathrm{g} / \mathrm{kg}$ of $\mathrm{DM}$ & 237 & 231 & 234 & 225 & 198 \\
\hline Hemicellulose $\mathrm{g} / \mathrm{kg}$ of $\mathrm{DM}$ & 215 & 189 & 190 & 179 & 147 \\
\hline Lignin $\mathrm{g} / \mathrm{kg}$ of $\mathrm{DM}$ & 65.4 & 64.2 & 63.9 & 59.5 & 57.8 \\
\hline In vitro dry matter digestibility $\mathrm{g} / \mathrm{kg}$ of $\mathrm{DM}$ & 669 & 702 & 714 & 734 & 810 \\
\hline $\mathrm{pH}$ & 4.8 & 10.7 & 11.5 & 11.8 & 12.0 \\
\hline
\end{tabular}


Table 2 - Chemical composition of sugarcane silage (means \pm standard error)

\begin{tabular}{|c|c|c|c|c|c|c|}
\hline \multirow[t]{2}{*}{ Variable } & \multicolumn{5}{|c|}{ Calcium oxide levels ( $\mathrm{g} / \mathrm{kg}$ as fed basis) } & \multirow[t]{2}{*}{$\mathrm{CV}(\%)$} \\
\hline & 0 & 5 & 10 & 15 & 20 & \\
\hline Dry matter $(\mathrm{g} / \mathrm{kg})$ & $253 \pm 13.1$ & $266 \pm 9.11$ & $282 \pm 7.13$ & $280 \pm 2.81$ & $279 \pm 2.59$ & 5.08 \\
\hline Organic matter $(\mathrm{g} / \mathrm{kg}$ of $\mathrm{DM})$ & $949 \pm 1.96$ & $932 \pm 3.04$ & $900 \pm 2.41$ & $870 \pm 1.92$ & $855 \pm 4.81$ & 0.58 \\
\hline Crude protein $(\mathrm{g} / \mathrm{kg}$ of $\mathrm{DM})$ & $28.0 \pm 2.50$ & $22.5 \pm 0.58$ & $23.2 \pm 0.50$ & $24.1 \pm 1.29$ & $20.2 \pm 1.00$ & 10.1 \\
\hline neutral detergent insoluble protein $(\mathrm{g} / \mathrm{kg})$ & $273 \pm 36.8$ & $273 \pm 14.6$ & $406 \pm 21.8$ & $407 \pm 54.1$ & $438 \pm 63.9$ & 20.4 \\
\hline Acid detergent insoluble protein $(\mathrm{g} / \mathrm{kg})$ & $158 \pm 12.9$ & $156 \pm 14.9$ & $150 \pm 18.8$ & $149 \pm 10.4$ & $148 \pm 3.62$ & 15.0 \\
\hline soluble carbohydrates $\mathrm{g} / \mathrm{kg}$ of $\mathrm{DM}$ & $121 \pm 7.74$ & $152 \pm 5.97$ & $135 \pm 2.74$ & $133 \pm 9.05$ & $155 \pm 1.62$ & 7.61 \\
\hline neutral detergent fiber $\mathrm{g} / \mathrm{kg}$ of $\mathrm{DM}$ & $629 \pm 0.76$ & $465 \pm 7.25$ & $437 \pm 9.02$ & $412 \pm 3.34$ & $379 \pm 14.4$ & 3.14 \\
\hline $\begin{array}{l}\text { neutral detergent fiber corrected for ash and } \\
\text { crude protein } \mathrm{g} / \mathrm{kg} \text { of } \mathrm{DM}\end{array}$ & $611 \pm 1,30$ & $448 \pm 7,86$ & $417 \pm 8,24$ & $389 \pm 4,18$ & $357 \pm 10,3$ & 1.93 \\
\hline acid detergent fiber $\mathrm{g} / \mathrm{kg}$ of $\mathrm{DM}$ & $422 \pm 4.97$ & $253 \pm 7.98$ & $257 \pm 9.11$ & $257 \pm 4.27$ & $226 \pm 8.74$ & 4.46 \\
\hline hemicellulose $\mathrm{g} / \mathrm{kg}$ of $\mathrm{DM}$ & $207 \pm 4.29$ & $212 \pm 1.27$ & $180 \pm 2.67$ & $155 \pm 1.20$ & $152 \pm 5.86$ & 3.38 \\
\hline Lignin $\mathrm{g} / \mathrm{kg}$ of $\mathrm{DM}$ & $80.9 \pm 14.6$ & $78.1 \pm 0.77$ & $65.0 \pm 1.53$ & $61.2 \pm 19.2$ & $79.5 \pm 8.50$ & 27.2 \\
\hline in vitro dry matter digestibility $\mathrm{g} / \mathrm{kg}$ of $\mathrm{DM}$ & $484 \pm 16.3$ & $656 \pm 9.52$ & $749 \pm 6.55$ & $782 \pm 20.6$ & $815 \pm 7.56$ & 3.29 \\
\hline $\mathrm{pH}$ & $3.4 \pm 0.015$ & $3.9 \pm 0.21$ & $4.3 \pm 0.18$ & $4.8 \pm 0.05$ & $5.3 \pm 0.13$ & 1.75 \\
\hline Ammonia-nitrogen $\%$ total nitrogen & $6.65 \pm 0.88$ & $11.0 \pm 1.77$ & $8.78 \pm 1.14$ & $7.20 \pm 0.09$ & $3.62 \pm 0.63$ & 10.5 \\
\hline
\end{tabular}

Table 3 - Regression equations for variables regarding chemical composition, in vitro digestibility, $\mathrm{pH}$ and ammonia nitrogen of sugarcane silages treated with calcium oxide levels

\begin{tabular}{|c|c|c|c|}
\hline Variable & Regression equation & $\mathrm{R}^{2}$ & P-Value \\
\hline Dry matter $(\mathrm{g} / \mathrm{kg})$ & $\hat{\mathrm{Y}}=259.471+13.1394 * \mathrm{C}$ & 0.67 & 0.0266 \\
\hline Organic matter $\mathrm{g} / \mathrm{kg}$ of $\mathrm{DM}$ & $\hat{\mathrm{Y}}=976.522-25.016 * \mathrm{C}$ & 0.99 & $<0.0001$ \\
\hline Crude protein ${ }^{1}$ & $\hat{\mathrm{Y}}=26.497-2.83048 * \mathrm{C}$ & 0.61 & 0.0089 \\
\hline neutral detergent insoluble protein $\mathrm{g} / \mathrm{kg}$ of $\mathrm{CP}$ & $\hat{\mathrm{Y}}=220.926+46.320 * \mathrm{C}$ & 0.84 & 0.0104 \\
\hline Acid detergent insoluble protein $\mathrm{g} / \mathrm{kg}$ of $\mathrm{CP}$ & $\hat{\mathrm{Y}}=152.2$ & & \\
\hline soluble carbohydrates $\mathrm{g} / \mathrm{kg}$ of $\mathrm{DM}$ & $\hat{Y}=139.3$ & & \\
\hline neutral detergent fiber $\mathrm{g} / \mathrm{kg}$ of $\mathrm{DM}$ & $\hat{\mathrm{Y}}=613.246-261.632 * \mathrm{C}+75.4312 * \mathrm{C}^{2}$ & 0.94 & $<0.0001$ \\
\hline $\begin{array}{l}\text { neutral detergent fiber corrected for ash and } \\
\text { crude protein } \mathrm{g} / \mathrm{kg} \text { of } \mathrm{DM}\end{array}$ & $\hat{\mathrm{Y}}=597.433-301.292 * \mathrm{C}+94.183 * \mathrm{C}^{2}$ & 0.85 & $<0.0001$ \\
\hline acid detergent fiber $\mathrm{g} / \mathrm{kg}$ of $\mathrm{DM}$ & $\hat{\mathrm{Y}}=399.343-232.542 * \mathrm{C}+77.538 * \mathrm{C}^{2}$ & 0.82 & $<0.0001$ \\
\hline hemicellulose $\mathrm{g} / \mathrm{kg}$ of $\mathrm{DM}$ & $\hat{\mathrm{Y}}=214.957-33.3055 * \mathrm{C}$ & 0.89 & $<0.0001$ \\
\hline Lignina $\mathrm{g} / \mathrm{kg}$ of $\mathrm{DM}$ & $\hat{\mathrm{Y}}=73.0$ & & \\
\hline in vitro dry matter digestibility $\mathrm{g} / \mathrm{kg}$ of $\mathrm{DM}$ & $\hat{\mathrm{Y}}=491.225+352.040 * \mathrm{C}-97.3094 * \mathrm{C}^{2}$ & 0.99 & $<0.0001$ \\
\hline $\mathrm{pH}$ & $\hat{\mathrm{Y}}=3.713+0.9100 * \mathrm{C}$ & 0.99 & $<0.0001$ \\
\hline Ammonia-nitrogen $\%$ total nitrogen & $\hat{\mathrm{Y}}=7.26553+67.3574 * \mathrm{C}-4.35916 * \mathrm{C}^{2}$ & 0.88 & $<0.0001$ \\
\hline
\end{tabular}

*t-test significant at $5 \%$.

due to lower losses in silages with calcium oxide levels. In silages, the fiber fraction can increase perceptually in dry matter with the production of gases and effluents once the soluble components are lost as insoluble fraction increases when the wall cell components (Van Soest, 1992) remain in silages. In case of alcoholic fermentation in control silages of sugarcane, the fermentation of $1 \mathrm{~mol}$ of glucose can produce 2 moles of water and 2 moles of $\mathrm{CO}_{2}$ with intense losses of dry matter and concentration fibrous components (McDonald et al., 1991) as well as crude protein contents in sugarcane silages without additive.

The neutral detergent insoluble protein content was adjusted to a linear growing model, in terms of calcium oxide level; acid detergent insoluble protein was not adjusted in any equation and had an average value of $152.0 \mathrm{~g} / \mathrm{kg}$ registered in the dry matter basis. The soluble carbohydrates were not influenced $(\mathrm{P}>0.05)$ by the addition of calcium oxide and registered an average value of $139 \mathrm{~g} / \mathrm{kg}$, indicating that, based on the original content of soluble carbohydrates in sugarcane in natura, $65 \%$ of this constituent, on average, was used during the process of fermentation (Table 1).

The contents of neutral detergent fiber, neutral detergent fiber corrected for ashes and protein and NDFap and acid detergent fiber were adjusted to quadratic models, with minimum values of $386.0,333.0$ and $225.0 \mathrm{~g} / \mathrm{kg}$ for calcium oxide levels of $17.3 ; 17.3$ and $13.8 \mathrm{~g} / \mathrm{kg}$, respectively. The contents of hemicellulose, however, decreased linearly, with reductions of 3.33 units for each unit of added calcium oxide. Its reduction can be explained by the degrading action of the alkalis on the ether connections between the fenolic and glicidic acids of the cell wall, exposing more hemicellulose and cellulose to the microorganisms. Acording to Castrillón et al. (1978) and Alcântara et al. (1989), alkalized substances are able to modify the fermentation process by 
presenting a better chemical composition, a reduction in the production of ethanol, more lactic acid and better dry matter digestibility; this results increases the consumption and weight gain of the animals. The relationship between the amount of neutral detergent fiber and soluble carbohydrates (up to 3.0) has been used to evaluate the nutritional value of sugarcane, indicating that neutral detergent fiber would not be limited to the consumption of dry matter and the supply of digestible energy for the animals (Rodrigues et al., 1997). The values observed for neutral detergent fiber/soluble carbohydrates of the studied silages were 5.2, 3.0, 3.2, 3.0 and 2.4 for calcium oxide levels of $0,5,10,15$ and $20 \mathrm{~g} / \mathrm{kg}$, respectively. Only the silages with 5,15 and $20 \mathrm{~g} / \mathrm{kg}$ of calcium oxide presented rates equal to or less than 3.0. This may suggest that there are smaller amounts of NDF at these calcium oxide levels as a result of greater alkaline hydrolysis.

Calcium oxide level did not influence $(\mathrm{P}>0.05)$ the content of lignin in the silages which was $73.0 \mathrm{~g} / \mathrm{kg}$ (Table 3 ). The variation in the lignin content observed in the present study can be attributed to losses during the silage fermentation, because according to Van Soest (1987), during the alkaline treatment, part of lignin and silica can be dissolved, suggesting that it might have happened some solubilization of lignin by calcium oxide effect, however, this effect could have been masked by increases of their content because of the carbohydrates losses during the fermentation and proportional increment in the dry matter. After ensilage the lignin value increased to $17.5 \%$, which can be explained by a higher concentration of ADF in the silage compared to fresh sugarcane. While Balieiro Neto et al. (2007) did not observe differences in the amount of lignin between the 5 and $10 \mathrm{~g} / \mathrm{kg}$ levels of calcium oxide, Pedroso et al. (2007) reported reductions in lignin of 78, 59 and $59 \mathrm{~g} / \mathrm{kg}$ for the silage control and those treated with 20 and $30 \mathrm{~g} / \mathrm{kg} \mathrm{NaOH}$, respectively. According to this author, $\mathrm{NaOH}$ as well as the calcium oxide break lignocellulose structures through alkaline hydrolysis, making cellulose susceptible of being hydrolized to hexoses and the hemicellulose to pentoses, sugars that can fulfill the energy requirements of ruminants. The soluble carbohydrate contents were not modified, because the no solubilization of lignin might be related to increases of organic acids in silages as calcium oxide levels increases favoring formation of acid lactic by lactic acid bacteria predominately in this silages (Table 4 ).

The contents of IVDMD on silages were adjusted to the quadratic model, with a maximum value of $801.0 \mathrm{~g} / \mathrm{kg}$ of dry matter assessed at the level of $18.0 \mathrm{~g} / \mathrm{kg}$ of calcium oxide. This value can be considered elevated for sugarcane silage and it surpasses $21 \%$ the value before the ensilage which can be explained by alkaline hydrolysis of the fibers fraction of the silage that reduces the intermolecular connections of the linkages of hydrogen, which tie molecules of cellulose and hemicelullose and, consequently, solubilizes and increases the digestibility of these fractions favoring greater digestibility (Jackson, 1977; Van Soest, 1987). Balieiro Neto et al. (2007) obtained rising values of IVDMD $(656,707,792 \mathrm{~g} / \mathrm{kg})$ for sugarcane silages prepared with $0,5,10$ and $20 \mathrm{~g} / \mathrm{kg}$ calcium oxide levels.

However, Moraes et al. (2008) did not find any improvement in the consumption, digestibility and performance of bovines when supplying them sugarcane treated with calcium oxide. The author suggest the absence of effects and the short time for occurrence of alkaline reactions but the 24 hour-period is not enough to promote alkaline intumescelly or expansion of wall cell and increase digestibility. This fact suggest that although the calcium oxide has fast effect on fresh sugarcane, the hot temperature of drying the sample in stove contributed to increase reactions and consequently to increase the IVDMD (Table 1), even so the effects additions of calcium oxide was more efficient in silages due bigger time of reactions on the lignocellulosics linkages, with consequent solubilization of hemicelluloses as higher the calcium oxide levels are (Table 2), however the increases of IVDMD on silages can contribute to the undesirable products of fermentation affecting animal consumption.

The $\mathrm{pH}$ of silage increased linearly with the addition of calcium oxide (Table 3), with values of 3.47 and 5.29 for silages with 0 and $20 \mathrm{~g} / \mathrm{kg}$ calcium oxide, respectively. This increase in $\mathrm{pH}$ is a function of the alkaline nature of calcium oxide. Greater $\mathrm{pH}$ values do not necessarily result in unsuitable fermentation with high contents of ammonia-

Table 4 - Production of gas and effluents and dry matter recovery (DMR) in sugarcane silages

\begin{tabular}{|c|c|c|c|c|c|c|c|}
\hline \multirow[t]{2}{*}{ Variable } & \multicolumn{5}{|c|}{ Calcium oxide levels ( $\mathrm{g} / \mathrm{kg}$ as fed basis) } & \multirow[t]{2}{*}{$\mathrm{CV}(\%)$} & \multirow[t]{2}{*}{ P-Value } \\
\hline & 0 & 5 & 10 & 15 & 20 & & \\
\hline Gas $\mathrm{g} / \mathrm{kg}$ of $\mathrm{DM}$ & $178 \pm 0.46$ & $64.7 \pm 1.55$ & $47.4 \pm 1.06$ & $44.8 \pm 1.65$ & $37.6 \pm 8.78$ & 9.49 & $<0.0001$ \\
\hline Effluent $\mathrm{kg}$ per ton (as fed basis) & $94.7 \pm 51.1$ & $79.6 \pm 48.3$ & $76.8 \pm 7.11$ & $58.4 \pm 30.9$ & $58.1 \pm 29.7$ & 8.71 & $<0.0001$ \\
\hline DMR $\mathrm{g} / \mathrm{kg}$ of $\mathrm{DM}$ & $819 \pm 47.0$ & $890 \pm 28.0$ & $954 \pm 24.7$ & $982 \pm 9.52$ & $973 \pm 9.08$ & 5.15 & 0.0008 \\
\hline
\end{tabular}


nitrogen and proliferation of undesirable bacteria, as observed in silages of other forages or in sugarcane without additives (Balieiro Neto et al., 2009). The ammonia-nitrogen was also adjusted to a quadratic model, with a maximum value of $98.8 \mathrm{~g} / \mathrm{kg}$ at the level of $7.7 \mathrm{~g} / \mathrm{kg}$ calcium oxide (Table 3). The values of soluble carbohydrates and ammonianitrogen indicate the occurrence of adequate fermentation, suggesting that the silage produced is of good quality based on these variables, according to Mahanna (1993) and McDonald et al. (1991).

The production of gas was adjusted to the regression equation $\hat{y}=16.8844-19.7467 * C+7.1072 * C^{2}\left(r^{2}=0.92\right)$; the smallest production of gas is estimated to be $31.8 \mathrm{~g} / \mathrm{kg}$ for a 13.9 level of calcium oxide and it is probably connected to the inhibition of the development of microorganisms, stabilizing the fermentation in the mass ensiled at this level of calcium oxide (Table 4). The yeast is mainly responsible for the $\mathrm{CO}_{2}$ production during the fermentation of soluble carbohydrate to ethanol in sugarcane silages. Through the alcoholic fermentation done by yeast, each molecule of glucose fermented produces two ethanol molecules, two carbon dioxide and two water molecules. The calcium oxide prevented the development of yeast by osmotic pressure caused by $\mathrm{pH}$ on the cells of yeasts, reducing the gas and effluent losses (Table 4) with calcium oxide additions. This shows that silage of sugarcane with calcium oxide levels below $14.0 \mathrm{~g} / \mathrm{kg}$ is more susceptible to the largest total loss of dry matter, related to losses of gas, preferably as $\mathrm{CO}_{2}$, or effluent reducing the nutritious value of silages.

The production of effluents decreased linearly with the addition of calcium oxide, according to the equation $\hat{y}=92.4333-18.8953 * C\left(r^{2}=0.93\right)$. This fact $($ Table 4$)$ can be explained by controlling heterofermentative of yeast and increasing Lactobacillus population, probably homolactics through which the production of $\mathrm{CO}_{2}$, water and ethanol is reduced (Schmidt et al., 2007).

In addition, the increase of dry matter recovery can also be explained by the capacity of water retention or hygroscopic effect of the calcium oxide, which results in small losses of dry matter because of a higher retention of effluents produced, as noted in Table 4. According to Moraes et al.(2008) in order for the addition of calcium oxide occurs, $1 \mathrm{~mol}$ of $\mathrm{H}_{2} \mathrm{O}$ for each mol of calcium oxide is required. In other words, for each $56 \mathrm{~g}$ of calcium oxide, $18 \mathrm{~g}$ of water is necessary, decreasing the effluent losses during fermentation mainly in most levels of additive.

The dry matter recovery of the stored mass was adjusted to the model $\hat{y}=84.3864+8.0139 * \mathrm{C}\left(\mathrm{r}^{2}=0.85\right)$. The dry matter recoveryfor the silage control was already larger than that observed in silages by Freitas et al. (2006) and smaller than that obtained by Pedroso et al. (2005). The biggest dry matter recovery of silages can be explained by the reduced production of gas and effluents in those silages treated with calcium oxide (Table 4). Santos et al. (2009) observed that 10 and $15.0 \mathrm{~g} / \mathrm{kg}$ levels of calcium oxide were effective in reducing dry matter losses and production of gas in the sugarcane silages, leading to an increased dry matter recovery.

The population of lactic acid bacteria in the sugarcane before ensilage is adequate as a result of the lactic fermentation of the stored mass, such that the losses ceases during fermentation, according to Muck (1991). The population of lactic acid bacteria in sugarcane increased or decreased to values of $10^{4}$ and $10^{6} \mathrm{cfu} / \mathrm{g}$ fresh forage found by Pedroso et al. (2005) and Alli et al. (1983) respectively. The initial population of molds and yeasts in the plant (Table 5) is similar to that of the $10^{6} \mathrm{cfu} / \mathrm{g}$ fresh forage obtained by Alli et al. (1983) before ensilage of the sugarcane.

The population of enterobacteria is higher in silages produced with calcium oxide.

Typically, the enterobacteria are substituted by lactic groups, and the $\mathrm{pH}$ in the environment is acidified (Muck, 1996). As Meesk et al. (1999) observe, the population of enterobacteria suffers a great reduction until the tenth day of ensilage, and it might disappear completely or not up to the end of the period of conservation of the forage. Commonly the silages produced with calcium oxide can not have their pH reduced (Pedroso et al., 2007; Santos et al., 2008; Amaral et al., 2009) so little fast reduction in $\mathrm{pH}$ to suppress the fermentations of sugars in acetic acid and another's products of fermentation. In this way, the population of

Table 5 - Populations of enterobacteria, lactic acid bacteria, molds and yeasts (fungi) before ensilage and in sugarcane silages treated with calcium oxide

\begin{tabular}{|c|c|c|c|c|c|c|c|}
\hline \multirow[t]{2}{*}{ Microrganism } & \multirow[t]{2}{*}{ Sugar cane } & \multicolumn{5}{|c|}{ Calcium oxide level ( $\mathrm{g} / \mathrm{kg}$ as fed basis) } & \multirow[t]{2}{*}{ Mean } \\
\hline & & 0 & 5 & 10 & 15 & 20 & \\
\hline & \multicolumn{7}{|c|}{ Silages } \\
\hline Enterobacteria $\log \mathrm{cfu} / \mathrm{g}$ of green matter & 5.45 & 3.64 & 3.85 & 4.09 & 4.15 & 4.66 & $4.07 \pm 0.17$ \\
\hline Lactic acid bactéria $\log \mathrm{cfu} / \mathrm{g}$ of green matter & 5.09 & 5.63 & 6.27 & 6.36 & 7.17 & 6.34 & $6.35 \pm 0.24$ \\
\hline Fungi $\log \mathrm{cfu} / \mathrm{g}$ of green matter & 6.72 & 5.11 & 5.76 & 5.12 & 4.11 & 4.29 & $4.87 \pm 0.30$ \\
\hline
\end{tabular}


enterobacteria was favored by high $\mathrm{pH}$ in silages with higher calcium oxide levels (Table 2). According to Santos et al. (2008) higher values of $\mathrm{pH}$ in silages treated with alcalinizants additives are caused by its tamponant power, because the dissociation of atoms in chemical additives produce ionic loads that neutralize ions hydrogen deriving of organic acid produced during fermentation.

As for the population of lactic acid bacteria in the silages, a more elevated population $\left(10^{7} \mathrm{cfu} / \mathrm{g}\right.$ silage $)$ was observed in the silage treated with $15 \mathrm{~g} / \mathrm{kg}$ calcium oxide. This calcium oxide level demonstrated the biggest dry matter recovery of stored mass (Table 4). The initial population of molds and yeasts in the plant was likened to the $10^{6} \mathrm{cfu} / \mathrm{g}$ fresh forage observed in the literature for sugarcane in natura. A smaller population of molds and yeasts $\left(10^{4} \mathrm{cfu} / \mathrm{g}\right.$ silage $)$ is noted in the silage treated with $15 \mathrm{~g} / \mathrm{kg}$ calcium oxide, which can explain the dry matter recovery of the mass ensiled with this calcium oxide level.

The yeasts cause considerable reductions in dry matter contents of silages for producing $\mathrm{CO}^{2}$, ethanol and water during fermentation of carbohydrates, however, the calcium oxide with its buffer characteristics (Bernardes et al., 2009), could have made improper conditions to development of yeast blocking its favorite fermentative route, favoring preferentially the lactic acid bacteria homofermentative in silages (Table 5) confirmed by reduction of gasses losses and increases of dry matter recovery with additions of calcium oxide.

The homolatic fermentation of lactic acid bacteria is more efficiently because it converts 1 mole of glucose into 2 moles of pyruvate, which are converted into 2 moles of lactic acid. It should yield $100 \%$ dry matter recovery and $99 \%$ energy recovery, while the dry matter recovery in yeast fermentation should be about $51 \%$, despite the same recovery of energy production (McDonald et al., 1991).

According to Santos et al. (2008), treating sugarcane with alkalinizing agents might inhibit effects of the additive on the development of yeast, therefore the silages treated with these products presented reduction of alcoholic fermentation, high concentration of soluble carbohydrates and minor production of gasses and dry matter losses, also under relatively high $\mathrm{pH}$ values.

The estimates of the dry matter degradability parameters show that, exception for control silage, other silages presented fraction A values above $500.0 \mathrm{~g} / \mathrm{kg}$ (Table 6), which is because of the alkaline action of calcium oxide. Considering that fraction A represents the portion of the plant that is readily available for ruminal microorganisms, the calcium oxide added to the silage contributed significantly to the addition of the dry matter degradability as a function of the increase in fraction $\mathrm{A}$.

Although the results about hydrolytic activity of calcium oxide on the fiber fraction of ensiled sugarcane (Siqueira et al., 2007; Balieiro Neto et al., 2009) were consistent, the obtained effects not always were translated into benefits to the animal. In a review by Schmidt (2008), there is a predominance of works without effects or null effects of calcium oxide in silages. Mari (2008) did not find effect in dry matter consumption of bovines supplied with silages added with calcium oxide. Calcium oxide improves solubilization of fiber fractions in sugarcane silages increasing the in vitro dry matter digestibility, however the benefits of these fractions could not be improved by the animal. According to McDonald et al. (1991), the products of fermentation could intervene in voluntary consumption of the animals. The ammonia, regarding to the enterobacteria populations, in high concentrations in silages, was associated to unsatisfactory animal performance, a result of lower voluntary consumption of dry matter. However, studies indicate that this component itself is not relevant for the reduction of consumption, but it is when associated to other variable deriving of undesirable fermentation like ethanol and volatile fatty acids (acetic acid lower $20 \mathrm{~g} / \mathrm{kg}$ in DM in silages with $250 \mathrm{~g} / \mathrm{kg}$ of DM) (Schmidt et al., 2007). The use of alkaline agents in silages of sugarcane may result in products of the fermentation related to negative ruminal metabolism and performance of animals fed with these ensilages.

Table 6 - Ruminal degradable dry matter parameters (DMDg) of the sugarcane silages

\begin{tabular}{|c|c|c|c|c|c|}
\hline \multirow[t]{2}{*}{ Calcium oxide level ( $\mathrm{g} / \mathrm{kg}$ as fed basis) } & \multicolumn{3}{|c|}{ DMDg parameters } & \multirow[t]{2}{*}{$\mathrm{R}^{2}$} & \multirow[t]{2}{*}{ P-value } \\
\hline & Fraction A & Fraction $\mathrm{B}$ & Fraction $\mathrm{Kd}\left(\mathrm{h}^{-1}\right)$ & & \\
\hline 0 & 305.8 & 237.2 & 0.020 & 0.86 & $<0.0001$ \\
\hline 5 & 513.5 & 233.2 & 0.016 & 0.67 & $<0.0001$ \\
\hline 10 & 535.0 & 297.2 & 0.012 & 0.91 & $<0.0001$ \\
\hline 15 & 553.9 & 269.3 & 0.017 & 0.83 & $<0.0001$ \\
\hline 20 & 587.5 & 233.7 & 0.020 & 0.84 & $<0.0001$ \\
\hline Mean & $499.1 \pm 49.8$ & $254.1 \pm 12.7$ & $0.017 \pm 0.001$ & & \\
\hline
\end{tabular}

$\mathrm{A}=$ soluble fraction $(\%) ; \mathrm{B}=$ insoluble potentially degradable fraction $(\%) ; \mathrm{kd}=$ fractional rates of degradation $\left(\mathrm{h}^{-1}\right) ; \mathrm{R}^{2}=$ coefficient of determination . 
The fraction B values showed little variation, registering an average value of $254.0 \mathrm{~g} / \mathrm{kg}$. An important characteristic of sugarcane is its elevated yield of the indigestible fraction of dry matter when likened to other grasses, and it is obtained by the equation $\mathrm{X}=100-(\mathrm{A}+\mathrm{B})$. Values of this fraction were estimated at 457.0, 253.0, 167.0, 163.0 and $178.0 \mathrm{~g} / \mathrm{kg}$ for calcium oxide levels of $0,5,10,15$ and $20 \mathrm{~g} / \mathrm{kg}$, respectively.

Regarding the relative parameters for the ruminal neutral detergent fiber degradability of the silages, the fraction $B$ presented values numerically greater in silages with 10,15 and $20 \mathrm{~g} / \mathrm{kg}$ of calcium oxide. This fact is probably due to the breakage of the connections between the fractions of cellulose and hemicellulose as a result of the alkaline hydrolysis of the calcium oxide (Van Soest, 1987). Thus, higher values of B (Table 7) are reflected in smaller values of the non-degradable fraction.

Fraction I of the neutral detergent fiber degradability of the ensilage control is much below the $451.0 \mathrm{~g} / \mathrm{kg}$ reported by Valadares Filho et al. (2006) for fresh sugarcane. Azevedo et al. (2003) and Fernandes et al. (2003) also reported increased values ranging from 524.0 to $617.0 \mathrm{~g} / \mathrm{kg}$ for sugarcane in fraction $\mathrm{I}$.

The lower values of fraction I in this silages might be related to period of harvesting the plants, around of 18 months after planting, plus the fact that this variety had lower fiber content and higher digestibility of this fiber (Oliveira et al., 2007) compared to another variety. In another study, calcium oxide showed extreme efficiency on the indigestible fractions of less structured wall cell, favoring the action and expansion of cellulose. The higher was the action, the greater was the calcium oxide levels.

The reduction of indigestible neutral detergent fiber values as calcium oxide levels increased is in agreement to the results of fraction I to the manner in which calcium oxide acts on the lignocelulosics fractions increasing $\mathrm{Kd}$. According to Detmann et al. (2004), the reduction of indigestible neutral detergent fiber in rumen allows a greater consumption of neutral detergent fiber by the animal, in particular a greater consumption of B fraction, so one can infer that the reduction of indigestible neutral detergent fiber fraction suggest greater animal consumption. However, greater consumption and performance of animals eating sugarcane silages have not always been observed maybe because the deriving products of fermentation can be affecting animal performance, making further studies necessary.

The addition of calcium oxide is a smaller portion of the non-degradable fraction of the neutral detergent fiber, which is probably related to the reduced amount of acid detergent fiber (Table 2) observed in the silages with additives, despite of the lack of relationship between ADIP and the non-degradable fraction of the fiber which is because of due to the alkaline hydrolysis from calcium oxide, as previously discussed.

Studies in which the degradability in situ of sugarcane silages treated with calcium oxide is evaluated are scarce in the literature; however, the effects of alkaline agents on the degradability of the neutral detergent fiber due to alkaline hydrolysis are well documented (Van Soest, 1987). Balieiro Neto et al. (2007) observed that the use of $1 \mathrm{~g} / \mathrm{kg}$ of calcium oxide was efficient in increasing the degradability of the sugarcane fiber in natura, however, preservation of non-fibrous carbohydrates is obtained with $2 \mathrm{~g} / \mathrm{kg}$ of calcium oxide in silages. The authors also point out that different reactions can take place among the oxide and the components of the fiber and/or sugars when the sample presents reduced availability of moisture, leading to false interpretations, for example, the effect of the additive.

The values of rates of degradation of the $\mathrm{B}$ fraction or digestion rate of the neutral detergent fiber of the silages treated with calcium oxide increased up to the level of $15.0 \mathrm{~g} / \mathrm{kg}$ of calcium oxide. High values of $\mathrm{Kd}$ can be really favorable because it implies in minimal ruminal residues and increases the possibility of leakage of the indigested fraction. Passage and degradation rates affect consumption in such a manner that high rates of degradation imply minimum ruminal residue and quick removal (Paterson et al., 1994). As

Table 7 - Ruminal degradable neutral detergent fiber parameters (NDFDg) of the sugarcane silages

\begin{tabular}{|c|c|c|c|c|c|c|c|}
\hline \multirow[t]{2}{*}{ Calcium } & \multirow[t]{2}{*}{ oxide levels ${ }^{1}$} & \multicolumn{5}{|c|}{ NDFDg parameter } & \multirow[t]{2}{*}{$\mathrm{R}^{2}$} \\
\hline & & $\mathrm{B}$ & I & $\mathrm{L}$ & $\mathrm{Kd}$ & $\mathrm{NDF}_{i}$ & \\
\hline & 0 & 524.7 & 340.6 & 3.14 & 0.008 & 338.0 & 0.95 \\
\hline & 5 & 500.4 & 323.3 & 0.02 & 0.010 & 241.8 & 0.95 \\
\hline & 10 & 525.5 & 292.7 & 0.99 & 0.016 & 149.2 & 0.97 \\
\hline & 15 & 531.8 & 255.4 & 2.77 & 0.019 & 141.7 & 0.98 \\
\hline & 20 & 552.6 & 227.9 & 1.24 & 0.017 & 95.0 & 0.99 \\
\hline
\end{tabular}

$\mathrm{B}=$ insoluble potentially degradable fraction $(\%) ; \mathrm{I}=$ non-degradable fraction $(\%) ; \mathrm{L}=$ lag time and $\mathrm{kd}=$ rates of degradation of the $\mathrm{B}$ fraction $\left(\mathrm{h}-{ }^{1}\right) ; \mathrm{NDF}_{\mathrm{i}}=$ indigestible NDF obtained after incubation for 144 hours. ${ }^{1} \mathrm{~g} / \mathrm{kg}$ as fed basis; ${ }^{2}$ mean \pm standard error. P-value $<0.0001$ 
Fernandes et al. (2003) point out, fresh sugarcane shows a slow rate of neutral detergent fiber degradation, approximately $0.02 . \mathrm{h}^{-1}$. Nevertheless, higher values for this characteristic (ranging from 0.02 to $0.03 \mathrm{~h}^{-1}$ ) have been registered (Campos et al., 2001; Azevedo et al., 2003).

The sugarcane silages evaluated in this study presented a low rate of degradation. However, the addition of calcium oxide resulted in higher digestion values for the silages. Therefore, treating the forage with hydrolytic substances results in considerable alteration in the structure and composition of the cell wall, including partial solubilization of hemicelullose which allows the microorganisms of the rumen to have a larger surface to collect from and, consequently, increasing the extension of the degradation of the polysaccarides (Merchen \& Bourquin, 1994).

\section{Conclusions}

The silages with $15 \mathrm{~g} / \mathrm{kg}$ calcium oxide results in greater lactic acid bacteria population and more accentually reduction of effluents. However, the additions above $10 \mathrm{~g} / \mathrm{kg}$ calcium oxide levels to sugarcane results in greater dry matter recovery of stored mass and a positive lactic acid bacteria population, as well as a smaller quantity of yeast, reduced losses by gases and effluents, indicating good fermentation. This calcium oxide levels results in greater in vitro dry matter digestibility, as well as in a lower non-degradable fraction I, favoring the potential ruminal degradability of dry matter and neutral detergent fiber in silages.

\section{References}

ALCÂNTARA, E.; AGUILERA, A.; ELLIO, R. et al. Fermentation and utilization by lambs of sugarcane harvested fresh and ensiled with and without NaOH. 4 - Ruminal kinetics. Animal Feed Science and Technology, v.23, p.323-331, 1989.

ALLI, I.; FAIRBAIRN, R.; BAKER, B.E. et al. The effects of ammonia on the fermentation of chopped sugarcane. Animal Feed Science and Technology, v.9, p.291-299, 1983.

ALLI, I.; BAKER, B.E.; GARCIA, G. Studies on the fermentation of chopped sugarcane. Animal Feed Science and Technology, v.4, p.411-417, 1982.

AMARAL, R.C.; PIRES, A.V.; SUSIN, I. et al. Cana-de-açúcar ensilada com ou sem aditivos químicos: fermentação e composição química. Revista Brasileira de Zootecnia, v.38, p.1413-1421, 2009.

ANDRADE, J.B.; FERRARI JR., E.; BRUNO, G. Valor nutritivo da silagem de cana-de-açúcar tratada com hidróxido de sódio e acrescida de rolo-de-milho. Pesquisa Agropecuária Brasileira, v.36, p.1265-1268, 2001.

AZEVÊDO, J.A.G.; PEREIRA, J.C.; CARNEIRO, P.C.S. et al. Avaliação da divergência nutricional de variedades de cana-deaçúcar (Saccharum spp.). Revista Brasileira de Zootecnia, v.32, p.1431-1442, 2003.

BALIEIRO NETO, G.; SIQUEIRA, G.R.; RAMOS, N.J. et al. Perdas fermentativas e estabilidade aeróbia de silagens de cana-de-açúcar aditivadas com cal virgem. Revista de Brasileira de Saúde e Produção Animal, v. 10, p.24-33, 2009.
BALIEIRO NETO, G.; SIQUEIRA, G.R.; REIS, R.A. et al. Oxido de cálcio como aditivo na ensilagem de cana-de-açúcar. Revista Brasileira de Zootecnia, v.36, p.1231-1239, 2007.

BARBOSA, M.H.P.; SILVEIRA, L.C.I. Cana-de-açúcar: Variedades, estabelecimento e manejo. In: SIMPÓSIO SOBRE MANEJO ESTRATÉGICO DA PASTAGEM - SIMFOR. 3., 2006, Viçosa, MG. Anais... Viçosa, MG: UFV, 2006. p.245-276.

BERNARDES, T.F.; REIS, R.A.; AMARAL, R.C. Chemical and microbiological changes and aerobic stability of Marandu grass silages after silo opening. Revista Brasileira de Zootecnia, v.38, p. 1-8, 2009.

BERNARDES, T.F.; REIS, R.A.; SIQUEIRA, G.R. et al. Avaliação da queima e da adição de milho desintegrado com palha e sabugo na ensilagem de cana-de-açúcar. Revista Brasileira de Zootecnia, v.36, p.269-275, 2007.

BOLSEN, K.K.; LIN, C.; BRENT, B.E. et al. Effect of silage additives on the microbial succession and fermentation process of alfalfa and corn silages. Journal of Dairy Science, v.75, p.3066-3083, 1992.

CAMPOS, F.P.; SAMPAIO, A.A.M.; VIEIRA, P.F. et al. Digestibilidade in vitro/gás de volumoso exclusivos ou combinados avaliados pelo resíduo remanescente da digestão da matéria seca e produção de gás. Revista Brasileira de Zootecnia, v.30, p.1579-1589, 2001.

CASTRILlÓN, M.V.; SHIMADA, A.S.; CALDERÓN, F.M. Manipulacion de la fermentacion em ensilajes de cãna de azucar y su valor acalcium oxidenticio para borregos. Técnica Pecuária em México, v.35, p.48-55, 1978.

DERIAZ, R.E. Routine analysis of carbohydrate and lignin in herbage. Journal of Animal Science, v.12, p.150-160, 1961.

DETMANN, E.; ZERVOUDAKIS, J.T.; CABRAL, L.S. et al. Validação de equações preditivas da fração indigestível da fibra em detergente neutro em gramíneas tropicais. Revista Brasileira de Zootecnia, v.33, p.1866-1875, 2004 (supl.1).

FERNANDES, A.M.; QUEIROZ, A.C.; PEREIRA, J.C.; et al. Composição químico-bromatológica da cana-de-açúcar (Saccharum spp L.) com diferentes ciclos de produção (precoce e intermediário) em três idades de corte. Revista Brasileira de Zootecnia, v.32, n.4, p.977-985, 2003.

FREITAS, A.W.P.; PEREIRA, J.C.; ROCHA, F.C. et al. Características da silagem de cana-de-açúcar tratada com inoculante bacteriano e hidróxido de sódio e acrescida de resíduo da colheita de soja. Revista Brasileira de Zootecnia, v.35, p.48-59, 2006.

GONZÁLEZ, G.; RODRÍGUEZ, A.A. Effect of storage method on fermentation characteristics, aerobic stability and forage intake of tropical grasses ensiled in round bales. Journal of Dairy Science, v.86, p.926-933, 2003.

HALL, M.B. Challenges with nonfiber carbohydrate methods. Journal of Animal Science, v.81, p.3226-3232, 2003.

JACKSON, M.G. Review article: The alkali treatment o straws. Animal Feed Science and Technology, v.2, p.105-130, 1977.

JONES, D.I.; JONES, R. The effect of crop characteristics and ensiling methodology on grass silage effluent production. Journal of Agricultural Engineering Research, v.60, p.73-81, 1995.

KUNG, JR., L.; STOKES, M.R.; LIN, C.J. Silage additives. Madison: American Society of Agronomy, 2003. p.305-360.

LICITRA, G.; HERNANDEZ, T.M.; VAN SOEST, P.J. Standardization of procedures for nitrogen fractionation of ruminant feeds. Animal Feed Science and Technology, v.57, p.347-358. 1996.

MAHANNA, B. Troubleshooting silage problems. In: STATE APPLIED NUTRITION CONFERENCE, 4., 1993, Wisconsin. Proceedings... Wisconsin, 1993. p.1-24.

MARI, L.J. Desempenho de bovinos de corte alimentados com rações contendo cana-de-açúcar (Saccharum officinarum L.) fresca ou ensilada e o padrão de fermentação e a estabilidade aeróbica das silagens aditivadas. 2008. $315 \mathrm{f}$. Tese (Doutorado em Zootecnia) - Escola Superior de Agricultura Luiz de Queiroz, Piracicaba. 
MCDONALD, P.; HENDERSON, A.R.; HERON, S.J.E. The biochemistry of silage. 2.ed. Aberystwyth: Chalcombe Publications, 1991. 340p.

MERCHEN, N.R.; BOURQUIN, L.D. Processes of digestion and factors influencing digestion of forage-based diets by ruminants. In: CONFERENCE ON FORAGE QUALITY, EVALUATION AND UTILIZATION, 1994, Lincolen. Proceedings... Madison: American Society of Agronomy, 1994. p.564-612.

MEESKE, R.; BASSON, H.M.; CRUYWAGEN, C.W. The effect of lactic acid and bacterial inoculant with enzymes on the fermentation dynamics, intake and digestibility of Digitaria eriantha silage. Animal Feed Science and Technology, v.81, p.237-248, 1999

MERTENS, D.R. Gravimetric determination of amylase treated neutral detergent fiber in feeds with refluxing in beakers or crucibles: collaborative study. Journal of AOAC, v.85, p.1212-1240, 2002 .

MERTENS, D.R.; LOFTEN, J.R. The effect of starch on forage fiber digestion kinetics in vitro. Journal of Dairy Science, v.63, p.1437-1446, 1980.

MORAES, K.A.K.; VALADARES FILHO, S.C.; MORAES, E.H.B.K. et al. Parâmetros nutricionais de novilhas de corte alimentadas com cana-de-açúcar tratada com óxido de cálcio e diferentes níveis de concentrado. Revista Brasileira de Zootecnia, v.37, p.1301-1310, 2008.

MUCK, R.E. Inoculation of silage and its effects on silage quality. In: INFORMATIONAL CONFERENCE WITH DAIRY AND FORAGe INDUSTRIES, 1996, Madison. Proceedings... Madison: USDFRC, 1996. p.43-51.

MUCK, R.E. Silage fermentation. In: ZEIKUS, J.G.; JOHNSON, E.A. Mixed cultures in biotechnology. New York: McGrow Hill, 1991. p.171-204.

NOCEK. J.E. In situ and other methods to estimate ruminal protein and energy digestibility: a review. Journal of Dairy Science, v.71, p.2051-2069, 1988.

NUSSIO, L.G.; SCHIMDT, P. Tecnologia de produção e valor alimentício de silagens de cana-de-açúcar. In: II SIMPÓSIO SOBRE PRODUÇÃO E UTILIZAÇÃO DE FORRAGENS CONSERVADAS, 2004, Maringá. Anais... Maringá: UEM/CCA/ DZO, 2004. p.1-33.

OLIVEIRA, M.D.S.; ANDRADE, A.T.; BARBOSA, J.C. et al. Digestibilidade da cana-de-acúcar hidrolisada, in natura e ensilada para bovinos. Revista Brasileira de Zootecnia, v.8, n.1, p.41-50, 2007.

ØRSKOV, E.R.; MCDONALD, I. The estimation of protein degradability in the rumen from incubation measurements weighted according to rate of passage. Journal of Agricultural Science, v.92, p.449-453, 1979.

PATTERSON, J.A.; BELYEA, R.L.; BOWMAN, J.P. The impact of forage quality and supplementation regimen on ruminant animal intake and performance. In: FAHEY JR., G.C.; COLLINS, M.C.; MERTENS, D.R. et al. (Eds.) Forage quality, evaluation, and utilization. Madison: ASA, 1994. p.59-114

PEDROSO, A.F.; NUSSIO, L.G.; PAZIANI, S.F.; et al. Fermentation and epiphytic microflora dynamics in sugarcane silage. Scientia Agricola, v.62, p.427-432, 2005.

PEDROSO, A.F.; NUSSIO, L.G.; LOURES, D.R.S. et al. Efeito do tratamento com aditivos químicos e inoculantes bacterianos nas perdas e na qualidade de silagens de cana-de-açúcar. Revista Brasileira de Zootecnia, v.36, p.558-564, 2007.

PIRES, A.J.V.; REIS, R.A.; CARVALHO, G.G.P. et al. Bagaço de cana-de-açúcar tratado com hidróxido de sódio. Revista Brasileira de Zootecnia, v.35, p.953-957, 2006.

ROBERTSON, J.B.; VAN SOEST, P.J. The detergent system of analysis and its application to human foods. In: JAMES, W.P.T.; THEANDER, O. (Eds.) The analysis of dietary fiber in food. New York: Marcel Dekter, 1981. p.123-158.

RODRIGUES , A.A.; ESTEVES, S.N.; PRIMAVESI, O. Efeito da qualidade de variedades de cana-de-açúcar sobre seu valor como alimento para bovinos. Pesquisa Agropecuária Brasileira, v.32, n.12, p.1333-1338, 1997.

SANTOS, M.C.; NUSSIO, L.G.; MOURÃO, G.B. et al. Influência da utilização de aditivos químicos no perfil da fermentação, no valor nutritivo e nas perdas de silagens de cana-de-açúcar. Revista Brasileira de Zootecnia, v.37, n.9, p.1555-1563, 2008.

SANTOS, M.C.; NUSSIO, L.G.; MOURÃO, G.B. et al. Nutritive value of sugarcane silage treated with chemical additives. Scientia Agricola, v.66, p.159-163, 2009.

SCHMIDT, P.; MARI, L.J.; NUSSIO, L.G. et al. Aditivos químicos e biológicos na ensilagem de cana-de-açúcar. 1. Composição química das silagens, ingestão, digestibilidade e comportamento ingestivo. Revista Brasileira de Zootecnia, v.36, n.5, p.1666-1675, 2007 (supl.).

SCHMIDT, P.; NUSSIO, L.G.; ZOPOLLATTO, M. et al. Aditivos químicos ou biológicos na ensilagem de cana-de-açúcar. 2. Parâmetros ruminais e degradabilidade da matéria seca e das frações fibrosas. Revista Brasileira de Zootecnia, v.36, p.1676-1684, 2007 (supl.).

SCHMIDT, P. Aditivos químicos e biológicos no tratamento de cana-de-açúcar para alimentação de bovinos. In: SIMPÓSIO SOBRE PRODUÇ̃̃O E UTILIZAÇÃO DE FORRAGENS CONSERVADAS, 3., 2008, Maringá. Anais... Maringá: Masson, 2008. p.117-152.

SILVA, E.J.A.; BORGATTI, L.M.O.; MEYER, P.M. et al. Efeitos do teor de carboidratos solúveis sobre as características da silagem de cana-de-açúcar. Revista Brasileira de Zootecnia, v.37, p.1375-1382, 2008.

SIQUEIRA, G.R.; REIS, R.A.; SCHOCKEN-ITURRINO, R.P. et al. Associação entre aditivos químicos e bacterianos na ensilagem de cana-de-açúcar. Revista Brasileira de Zootecnia, v.36, p.789-798, 2007

SIQUEIRA, G.R.; REIS, R.A.; SCHOCKEN-ITURRINO, R.P. et al. Perdas de silagens de cana-de-açúcar tratadas com aditivos químicos e bacterianos. Revista Brasileira de Zootecnia, v.36, p.2000-2009, 2007 (supl.).

STATISTICAL ANALYSIS SYSTEM - SAS. User's guide Cary: 2003. (CD-ROM).

VALADARES FILHO, S.C.; MAGALHÃES, K.A.; ROCHA JR., V.R. et al. Tabelas brasileiras de composição de alimentos para bovinos. Viçosa, MG: Universidade Federal de Viçosa/DZO, 2006. 329p.

VALVASORI, E. Avaliação da cana-de-açúcar em substituição a silagem de milho para vacas leiteiras. Arquivo Brasileiro de Medicina Veterinária e Zootecnia, v.32, p.224-228, 1995.

VAN SOEST, P.J. Nutritional ecology of the ruminant. 2.ed. Corvallis: O \& B Books, 1987. 373p. 